Article

\title{
Oromo Orature: An Ecopoetic Approach, Theory and Practice (Oromia/Ethiopia, Northeast Africa)
}

\author{
Assefa Tefera Dibaba
}

Department of Oromo Language, Folklore, \& Literature, College of Humanities, Languages, Communication, \& Journalism, Addis Ababa University, Addis Ababa 1176, Ethiopia; asafadibaba@gmail.com

Received: 17 January 2020; Accepted: 23 March 2020; Published: 31 March 2020

check for updates

\begin{abstract}
Using available empirical data of Oromo Orature, particularly folksongs, obtained from the field through interview and observation in Oromia, central Ethiopia, in 2009 and 2010, and other sources in print, this study has two objectives to tackle. First, reflecting upon the questions of a native model of origin narratives in relation to ecology, this study examines some examples of Oromo ecopoetics to determine: (a) how ecology and creative process conspire in the production of folksongs and performance, and (b) how the veil of nature hidden in the opacity of songs is revealed through the rites of creative process and performance as the human and ecological realms intersect. When put in relation to ecology, I theorize, the ecocultural creative act and process go beyond the mundane life activities to determine the people's use (of nature), perceptions, and implications. Second, damages to the ecology are, I posit, damages to ecoculture. Drawing on the notion of ecological archetypes, thus, the study makes an attempt to find a common ground between the idea of recurrent ecological motifs in Oromo orature and the people's ecological identity. The findings show that the political and social attitudes the Oromo songs embody are critical of authorities and the injustices authorities inflict on peoples and the environment they live in. For the folksinger, singing folksongs is a form of life, and through performance, both the performance and the song sustain the test of time. In its language, critique, imagination, and cultural referents, Oromo Orature is a voice of the people who rely on traditional agricultural life close to nature along with facing challenges of the dominating religious, political and scientific cultures.
\end{abstract}

Keywords: ecology; orature/folksong; ecoculture; creative process/act; ecopoetics; Oromo/Oromia/ Ethiopia; ecological archetypes/identity; performance; indigenous practices; tradition ecology; ecology of mind

"The major problems in the world are the result of the difference between how nature works and the way people think." -Gregory Bateson

\section{Introduction}

The main aim of the present research is to clarify the ecopoetic features of Oromo orature and its role to inform both the local ecological knowledge and the modern environmental scholarship, to initiate empowerment of the local population to take part actively in decision-making and influence policies about what affects their life and the environment in which they live. In this article, I analyze a few cultural expressions to draw out the relationship between the Oromo and the ecosystem they inhabit and depend on. The study will naturally focus on a symbolic connection between expressive cultures and ecopoetic practices to examine their relationship to the direct experience of the people, i.e., ecological identity. 
The Oromo are the most populous single ethno-nation in Northeast Africa and they constitute the larger portion of the inhabitants of Ethiopia (Central Statistical Agency 2010). They speak Afaan Oromoo (Oromo Language), a Cushitic branch, which is spoken in Ethiopia and Kenya and is the fourth widely spoken language in Africa after Arabic, Swahili, and Hausa (Lodhi 1993).

Luling (1965) reminds us, "from the mid-sixteenth to the mid-nineteenth century the [Oromo] were dominant on their own territories; no people of other cultures were in a position to exercise compulsion over them" (Luling 1965; see also Tibebu 1995). The Oromo are agricultural communities with a culture enriched by folksongs, myths, and ecological archetypes as a result of their ecological adaptations developed over time about their traditional pattern of life and constant interaction with nature. Today, a small-scale agriculture is identified as the major cause of deforestation and environmental degradation in Oromia (Ministry of Environment, Forest and Climate Change, Ethiopia/Oromia 2017). Currently, the Oromo are in some debate about what constitutes the human good when things fall apart and how to endure life in adverse conditions as the political uncertainty is unfolding in Ethiopia. Thus, the Oromo engaged in a painful history of subjugation and alienation in the traditionally dominant Abyssinian Orthodox Christian culture and are attempting to redress persistent inequities and unequal historical relationships in the face of denial from Abyssinian elites.

\subsection{Purpose}

The purpose of this study is to establish the ecopoetics of Oromo Orature as a compelling case for a transformative cultural agency and to explore the ethically challenged human-ecology relationships. Using some examples from Oromo Orature, it is argued that ecopoetics is an ecocultural creative process, an act of aesthetic force of a green discourse that extends the human-ecology nexus beyond mundane activities and use of nature to understand the local perceptions/beliefs and their implications about the human close observation of, empathic interaction and ethical relationship with nature. In the present research project, ecopoetics takes, as its focal point, the humankind responsible for the precarious state of the natural world as a result of the ongoing eco-colonialism and continuous urban expansion. To advance this cause and to decry the enduring environmental injustices intensified by insatiable material pursuit, this project made an attempt to reimagine folklore and ethnoecology scholarship (academic or public) as a way of merging socioeconomic reality with environmentalism and as a platform for providing a face for the invisible but real presence of eco-colonialism both in industrialized and developing countries. The examples discussed in this study show that by singing their dislocated memories about the degradation and eviction from their home, the Oromo made a choice to keep their environmental history and to critique the social and environmental injustices through a folkloric representation of the dire human condition and the debilitating environment, past and present.

\subsection{Research Questions and Objectives}

The texts collected through interviews and from available sources presented here are masterpieces of those dominant spaces (secular and sacred): hills, rocks, waterholes, trees, rivers, lakes, mountains, grasses and other natural features which signify peace, permanence, abundance, strength and durability, and fertility, as embodiments of the Oromo "tradition ecology". Those dominant places presented in Oromo Orature are associated with the activities of ancestral beings collectively known as ayyaana, who, like Lauri Honko's "barn spirit" or the spirits summoned upon the buuta festival of the Siri epic, are supernatural entities no less ancient than the landscape itself, and believed to travel across the land and protect the physical and socio-cultural world that the Oromo inhabit.

\subsection{Objectives}

There are two objectives of the study: First, reflecting upon the questions of an indigenous model of origin narratives in relation to ecology, this study examines some examples of Oromo ecopoetics to determine: (a) how ecology and creative process conspire in the production of folksongs and performance, and (b) how the veil of nature hidden in the opacity of songs is revealed through the rites 
of creative process and performance as the human and ecological realms intersect. When put in relation to "tradition ecology", I theorize, the ecocultural creative act and process go beyond the mundane life activities to determine the people's use (of nature), perceptions, and implications. Second, damages to the ecology, I posit, are damages to ecoculture. Drawing on the notion of ecological archetypes, thus, the study makes an attempt to find a common ground between the idea of recurrent ecological motifs in Oromo Orature and the people's ecological identity.

\subsection{Research Questions}

The study aims to answer the inquiries of folkloric and ecocultural nature which will feature a close exploration of human-ecology relationships in Oromo Orature: What is ecopoetics? What are the implications of the social-ecosystem destruction from an ecopoetic perspective? How do those implications of damages to the Oromo ecoculture affect their Orature and the effort to determine the future of a sense of place in its present local/global dimensions?

\subsection{Organization of the Study}

To proceed, first, a background is set to this ecologically-oriented study of Oromo Orature with a brief history of the people (Oromo) and their homeland (Oromia), objectives and research questions under the introduction section. In the literature review section, since ecopoetics sets the stage for theorizing local ecological knowledge and practices, focus is on elaborating ecopoetic perspective to ecology and folklore in general and to Oromo ecoculture and Orature, in particular. To lay a fertile ground for indigenous (Oromo) folklorists, ecopoets, and ethnoecologists, this section presents how different environmentalists have used local ecological knowledge and archetypes, and the advantage this transdisciplinary approach has to study Oromo ecocultural creativity from the ground up and in relation to the world. In the methodology section, the "interview" and "personal observation" techniques are discussed as convenient methods/tools to obtain relevant information, followed by the data presentation and analysis section where the data is relocated back to its Oromo historical, folkloric, and cultural background in Oromia, Ethiopia, to date, to answer the questions of folkloric and ecological nature. The study concludes that the Oromo Orature is a rich source of ecopoetic data to synthesize the indigenous ecological knowledge system into a meaningful analytic whole from the ground up.

\section{Ecopoetic Perspective}

We live in the age of social and environmental crisis. Humanity is to blame for the ethically challenged relationships with the environment and for the anthropocentric damages made to Dachii/Mother Earth. The crisis demands a new way of thinking, being, and acting for humankind to unlock the possibilities and potentials passed down in cultural resources and to maintain resilient transformation in the face of rapid social changes and cultural dynamics. In what follows, I present two concepts deemed relevant and significant to the purpose of this study: Lauri Honko's "tradition ecology" and Gregory Bateson's "ecology of mind".

I consider Lauri Honko's concept of "tradition ecology" as a relevant model, which views "'the environment' to incorporate both the natural and the cultural environment" (Kamppinen 2014, p. 17; see also Kamppinen and Harkamies 2012). "Tradition ecology" was Honko's key theoretical model used to approach the relations of traditions to one another and to society, both in diachronic and synchronic terms. In his research topics that ranged from folk beliefs, myths and rituals, ethno-medicine, oral epics, and cultural identity, Lauri Honko used his "tradition ecology" approach as a unifying theme in both fields of folkloristics and comparative religion. For instance, around a "barn spirit", a set of folkloric and traditional/religious activities are intertwined: to sing about, talk about, describe, narrate, be possessed and experience, embed in memories, and pass it on to succeeding generations as a cultural construct "in the process of tradition" and "cultural actions and interactions" (Kamppinen 2014, pp. 14-15). Similarly, the notion of "environmental determinism", which explains 
"cultural facts by means of environmental conditions" (p. 15) exemplifies the Salale Oromo accounts of the "origin theory" of orature, folksongs in particular, which holds that the physical world and sacred places (rivers, mountains, caves, trees, groves, hilltops) are unique sites for poetic meditation and composition. It is a local ecological perspective that considers the relationship between human cultural contents and their environment as close and indispensable entities. Thus, the underlying principle of "tradition ecology" is that cultures should be studied in their contexts, which is an obvious case for the purpose of the present study to relocate an Oromo orature within the context of Oromo cultural ecology.

Gregory Bateson, in his book, Steps to an Ecology of Mind (1974, 1984), applied systems theory (cybernetics) to the fields of social sciences and ecology to enable us to understand the functioning of the natural world through understanding an "ecology of mind", which is how ideas fit together in an integrated system. By "mind/s", Bateson meant the "new way of thinking about ideas and about those aggregates of ideas" (p. 13). Bateson's works focused on anthropology, psychiatry, biology, and the "new epistemology", which he says, "comes out of systems theory and ecology," subjects that have been central to his thinking (Bateson 1987, p. 12). Mary Catherine Bateson, in her prefatory note to the 1987 edition, confirms that to express the "interface between the realm of mind and physical reality" and "the way in which mental process establishes landmarks or thresholds, meanings and definitions in the world of flux," Bateson repeatedly quoted Heraclitus: "Into the same river no man can step twice" (Bateson 1987, p. 8).

Bateson (1987), in his "The Roots of Ecological Crisis" argues that the causes of environmental degradation "lie in the combined action of (a) technological advance; (b) population increase; and (c) conventional (but wrong) ideas about the nature of man and his relation to the environment" (p. 343). The latter cause relates to the present day unethical relationship of man toward nature which, according to Bateson, dates from the Industrial Revolution (p. 345):

(a) It is us against the environment.

(b) It is us against other men.

It is the individual (or the individual company, or the individual nation) that matters.

We can have unilateral control over the environment and must strive for that control.

(c) We live within an infinitely expanding "frontier".

(d) Economic determinism is common sense.

(e) Technology will do it for us.

Bateson adds that these ideas "appear to be false under modern ecological theory. The creature that wins against its environment destroys itself" (p. 345).

In sum, one can pool the two views together as follows: (a) from Lauri Honko's notion of "tradition ecology", environmental determinism explains "cultural facts by means of environmental conditions", and (b) from Gregory Bateson's view of "ecology of mind", economic determinism governs the relationship between humanity and the environment in which they live, the unethical relationship that dates to the Industrial Revolution. From both views, it is obvious that there is an acute need for a "new way of thinking about ideas and about those aggregates of ideas" called "mind/s" to better understand the "interface between the realm of mind and physical reality", from the perspective of relations of traditions to one another and to society in time and place (Bateson, ibid., p. 13). It is a cultural critique, which I call ecopoetics, of this unbalanced relationship presented in this study using some expressive cultures/orature from Oromia, Ethiopia.

\subsection{What Is Ecopoetics?}

To ease some burden of methodological absurdity or theoretical incongruity, I explained the concept "ecopoetics" in my PhD thesis (Dibaba 2015) as follows: 
I use "eco" to refer to "nature," "natural habitat," "land/space," or "house/home," and "poetics," that is, "poesis" or "making." Hence, "making a house," where both human and nonhuman inhabit. In so doing, I do not necessarily focus on the "critical" over the "creative" act but I will try to balance both. To make it more explicit, here my intention is that, if ecocriticism is an unheeded impetus of a call for [ecological] actions in studies like comparative literature, let ecopoetics do the job in folkloristics.

Ecocriticism is an ecological literary criticism, an 'activist' environmentalist praxis that studies the relationship between literature and the environment, a commitment deeper than professionalism, whereas, ecopoetics is the poetics of ecology - the relationship between humans and their environment (Estok 2009). The etymological explanation of ecopoetics shows that "it is the poetics of place ... a linguistic combination of ecology and poetics which foregrounds the intertextuality and interdisciplinarity that typifies ecopoetic discourses as well as the 'ecological imperative that in the UNIVERSE everything is connected to everything else'" (Labang 2015).

An ecopoetic perspective and ethnoecological study of human-environment relation/ transformation is a most pressing and practical scholarly concern at this time. Some may consider this effort of "creating visibility for vernacular worlds in a democratic public sphere" as "civic professionalism", a "professionalism opposed to the narrowing implicit in its technical form, a professionalism designed to complement and strengthen a new civil politics" (Hufford 1999). It is our responsibility as folklorists "to help cultivate local and regional identities in places hard hit by global economic restructuring and related displacements (Hufford, ibid.). In this continuous process of ecopoetic knowledge construction, the role of the folklorist ethnoecologist is "not about the building of knowledge, but about illuminating what Foucault terms the 'insurrection of subjugated knowledge,"' the insurrection which "is always at risk of being contained, domesticated, and marginalized by a status of folklore" (Hufford, ibid.; see Jalata 1996). This is an attempt to model ecopoetics on local epistemology to produce an engaged ethnographic knowledge (ethnomethodology), which is a form of collaborative endeavor. So, if "criticism" is an expression of "disapproval" based on perceived faults or mistakes, or the analysis and judgment of the merits and faults of ideas, beliefs or principles and practices, I bet we need "ecopoetics" both as a creative process and critical act, and as an alternative method of analysis in ecocultural creativity studies instead of "ecocriticism" —an environmentalist activist literary stance primarily focusing on written environmental literature (Adugna 2014). Although, in ecocriticism, "the phrase 'environmental literature' is used to describe all literary forms (oral, poetry, fiction, nonfiction, and drama) that investigate human-nature relationship," "ecopoetics," I suggest, is more suitable than "ecocriticism" for the art and craft of ecocreative process and critical acts we do as folklorist ethnoecologists (Slovic 1999; see also Adugna ibid., p. 27).

\subsubsection{Folkloric Ecopoetics}

Now, folkloric ecopoetics is understood as an ecocreative human communication with the nonhuman, a meditative human connectedness to nature. This meditative communication involves prayers, composing and singing songs, telling stories, naming totems, idolizing deities and offering tree coronations, summoning and glorifying God at hilltops, sacrifices at river banks, libations in farmyards, visiting graveyards and tabooing sacred groves, symbolizing and dedicating earthlings and communicating kind relationships between humankind and nature, which is wrapped up in the notion of the Oromo Irreecha festival (Shunkuri 1998). Through this ecopoetic mediation, humans learn to struggle to find and reclaim the place they call "home".

Put within the backdrop of the Oromo worldview, the present folkloric ecopoetics is a theory and praxis of deliberate earthlings, conscious life-form close to nature in the locale contrary to or complementary with the dominant Orthodox Christian culture. Conceived as a site, perhaps not as a genre, folkloric ethnopoetics here explores the idea that consciousness and agency are distributed "out there," amongst the "objects" of the outside world, not in here in the human "subject" (Latour 2011). The Oromo venerate those places as sublime gifts inherited from their predecessors, and at some point 
in history, that transcendent gift was confiscated and became a symbol of the "unknown", what is "unforeseeable" but "possible" for generations to contemplate "waan-hafe", i.e., "a historical loss".

\subsubsection{Local Experiences, Global Processes}

The term "local" in "local knowledge" or "local institution" refers to "a residual category equated with whatever is not national", and, I should add, what is not "global" or "universal" (Jeremias et al. 2011). In ethnographic search, the "local" is a source for collecting, analyzing, and evaluating relevant data about what can be considered part of the whole. The "national" or the "global" cannot be unaffected by the "local" as the "local" provides basis for a collective action and consensus on decision-making about what affects the life of the people at the local level and the environment in which they dwell, and vice versa. So, it is fair enough to argue that local experiences of the environment are inevitably also global ones, "but our experiences of the global are often local" and "indeed, "have to be rooted in local perceptions and experiences'" (Gifford 2012).

In his Wisdom Sits in Place, Basso brings to our attention that "constructions of reality that reflect conception of reality, the meaning of landscapes and acts of speech are personalized manifestations of a shared perspective on the human condition," which is corollary with what Basso notes as saying, "local understandings of external realities are fashioned from local cultural materials" (Basso, 1996). When people, who know each other better have more rapport and sense of belonging at the local level, are removed from their home, their opportunities for cooperation and collective action on a self-ruling basis is shuttered, and the shared values and "ecological knowledge" is disrupted (Jalata 2012). The local institutions that include rainmakers, council of elders, traditional midwives, artisans and ritual leaders of sacred groves and tree coronations disintegrate as a result of the removal and occupation of the indigenous peoples. The roles of local institutions range from lineage organization, village-level governance, and common resource management to conflict resolution and mediation with waaqa (god), ayyaana (spirits) and dachii (mother earth) according to the safuu moral system. The 1880s' conquest disrupted the Oromos' potential to achieve human-environmental transformation outcomes and to practice the environmentally sustainable, economically viable and culturally acceptable natural resource management.

\subsubsection{African Ecopoetics}

An African ecopoetics can be exemplified by verbal arts and performances as in this nature song of Zulu children (WebCite) while they stalk about [Text 1]:

Walking through Africa, what do I see?

I can see inyoka looking at me.

Walking through Africa, what do I see?

I can see ufudu looking at me.

Walking through Africa, what do I see?

I can see indlovu looking at me.

Walking through Africa, what do I see?

I can see ikhozi looking at me.

The Oromo children's rain song next is another example of a nature song I remember [Text 2]:
Bokke bokkee na guddisi
Oh rain nourish me to grow
Wayyaa furdaa natti huwwisi
Dress me thick and warm to glow.

Running naked in the rain, jumping and chanting this and other rain songs is not just fun but it also ties the knot of children-nature relations tightly as it sets the children's aspirations "to grow" and "to glow". Rain represents fertility, which is of the utmost importance to all, and it symbolizes a regeneration of life, crops and healing plants. When the sky releases rain, most obviously it is believed, 
the sky god's (waaqa) semen wets Dachi's womb. Hence, the fecundity of Mother Earth is a prosperity and peace for the living, a life-bringing and sustaining prospect.

The works of African ecopoets, particularly the environmentally conscious Nigerian poets, among others, Tanure Ojaide, Niyi Usundare, and the martyred poet from Ogoniland, Saro-Wiwa (1996), vocalize the people's reclaiming of the broken places, and the polluted socio-economic landscape in their writings (WebCite). The poets used poetry "to address as well as to bring to the knowledge of humanity this form of environmental devastation and inhumanity" (ibid.). Saro-Wiwa (1996), for example, wrote the following message from prison against oil companies' environmental destruction in his native home of Ogoniland: "The environment is man's first right. Without a safe environment, man cannot exist to claim other rights, be they political, social, or economic" (WebCite). For Saro-Wiwa (1996), ecopoetics, i.e., the poetics of ecology, is not just an environmentally oriented literary criticism, or activist impulse and ambitions, but a creative act, a serious commitment deeper than mere civic professionalism.

The postcolonial African ecopoetics examines the poetics of other-than-Western cultures-that of the Sub-Saharan Africa-to show how the peoples use the environment and to reveal their encounters, the historical, cultural, and personal realities which shape the environmental experience from an African perspective (Mawere 2013). The local environmental crisis is "uniquely important because local/regional activities have global consequences and so writers/critics must respond in ways that best reflect their cultural philosophies and individual perceptions of the environment" (Labang 2015). To the postcolonial local folklorist, ecopoetics is not just an aesthetic decision/strategy used to reveal how the ecological consciousness manifests itself but is part of the local folklorist's existential worldview and ontological historicity. It is distressing that "[t]here is virtually no landscape, no ecosystem on this planet that has been untouched by human intervention, by technology and its byproducts" (Labang, ibid.; Arigo). The truth is, in postcolonial context, societies have different relationships with the environment and their ontological philosophy or worldview (local epistemological veracity). It is problematic to understand the human-ecological relations, i.e., use, perceptions and beliefs, implications about how to experience, perceive, represent, and interact with environmental forces from purely Western discourses. In discussing different worldviews and significances of the environment in different cultures, Oscar Labang rightly argues, "The forest to the American is an aesthetic function or commercial value, whereas to the African it is an existential and spiritual life force" (Labang, ibid.). By Oromo ecopoetics, expressive culture shows more than the aesthetic and instrumental function of ecology, with also the spiritual.

\subsubsection{Ecological Identity}

The childhood memories of place, perception of broken places, desecrated sites, and myths built around dominant spaces (mythscape) constitute our ecological identity (Thomasshow 1996). The local chiefs and ritual leaders in rural Africa are environmental archetypes who serve as role models for their community by their age-long practical knowledge of living close to nature. The Oromo ritual leaders and local ecological knowledge bearers are no exceptions: they impact the cultural transmission and social transformation from "below" but are marginalized from decision-making.

In the USA, indigenous peoples represent about 700 distinct communities who possess detailed ecological knowledge of their homelands and are the stewards of fully $4 \%$ of the land area (Durning 1992). The classic environmentalists include, among others, Henry David Thoreau, who lived in the early 1800s contemplating nature and learning natural history in Walden Pond, John Muir who lived close to nature in the High Sierras in the late 19th century, and Rachel Carson, who challenged humanity's faith in technological progress by merging her passion for literature and science and set the stage for the environmental movement through her canonic Silent Spring in the 1960s. The local chiefs and ritual leaders in rural Africa who transmit knowledge through ecological practices of everyday life and the environmental practitioners who lived close to nature use "ecology both as science and metaphor, lending coherence to human-nature relationships," and constitute an ecological identity deeply informed by personal reflections (Thomasshow, ibid.). Ecopoetics examines repetitive universal 
forms and dynamic patterns which reveal human capacities and experiences persistent in different cultures and folklore throughout the world (e.g., common motifs in sacred ecology, nature-related belief systems, lore, and rituals). Oromo folksongs are heavy-laden by ecological archetypes. Hence, studying ecological identity is one aspect of peeling away the thick layers of disenchantment and human alienation from nature.

\section{Methodology}

To collect relevant data from the site and to answer the research questions of folkloric and ecological nature, I used interviews, observations, and field-notes on the local ecological culture. I first began collecting Oromo folksongs in Salale on my PhD fieldtrips in 2009 and 2010 for my PhD data on Oromo folklore and resistance culture, and I was fascinated by the local indigenous culture and the people's knowledge of place and ecology in the area. Through revisiting the data, my field-notes and sources available in print, I later realized that the Oromo people's deep understanding of, connection with, and love for their land, land resources and environment was, and still is, immense. The mythscapes and dominant places named after ancestors, deities, historic events or the natural features a particular place displays impressed me most. However, at the time, my primary research focused on social justice, not on environmental justice per se.

Interviewing the local people in Oromia, northwest of Finfinne (Addis Ababa), the capital, and recording them singing and performing were the main activities in the fieldwork. In the interviews, I asked the informants (who chose to remain anonymous) to reflect on Oromo cultural ecology, on what is sacred and secular in their domain, on indigenous ecological practices, on indigenous agricultural knowledge, on alternative ways of balancing human-ecology solidarity, and on the challenges to and limitations of indigenous ecological practices. Throughout the interview process, I obtained not only information (facts, names and dates) from the interviewees, but also insights, thoughts, attitudes, beliefs and practices relevant to cultural ecology and Orature.

\section{Some Oromo Ecopoetic Practices: Data Presentation and Analysis}

The songs and narratives in this study mark the transition of the people's direct experience, a self-reflexive embodiment of the ecocreative process, a transition from nature to culture and vice versa, not in the sense of the Western nature-culture duality principle but in the force of living interconnectedness that both articulate and transcend the differences (Okpewho 1992; Okpewho 2007). In what follows, I look into a human expression, and the narratives of Oromo origin theory, to set in context the Oromo perspective of inseparable human-environment nexus. Not only is the poetic persona in Oromo folksongs very often mythic but the landscape is also mythicized as a reflection of the past to create a mythscape.

\subsection{Oromo Origin Narrative}

Next, Oromo origin stories are more my base of operations than my main subject, which is the ecopoetic study of Oromo orature. So, one environmentally directed story goes, Uume Walaabuu baate [Text 3], meaning, Uume (Creation) began at Walaabu (Baisa 1995; Deme 1998; Ehret 1976). The Oromo people largely believe this story to be the genesis of Mother Nature/Earth at Walaabu, eastern Oromia, Ethiopia. Storying an "origin" without being there may seem strange. However, Bruno Latour (Latour and Strum 1986) and Strum, in their "Human Social Origins" alert us:

... there is no difference between scientific stories (falsifiable) and mythical stories (unfalsifiable); an explanation is always a story ... When E.O. Wilson, Nietzsche, Freud, or Dawkins tells us how social bonds first originated, they are not describing something that happened in front of their eyes .... (See also Latour 2011)

According to Oromo origin theory and time concept (which is cyclical, not linear), the beginning of Life (Uuma) in Oromo worldview is in relation to "place". Hence, by this account 
of environmental/spatial imagination, the ecopoetics of Oromo folksong origin relates to the Dawn of Creation (Uumaa Ganamaa) which the Oromo believe took place at Walaabu, also referred to as Fugug or Tulluu Nam-dur — the mountain of ancient humans. The place names "Haroo Walaabu," "Fugug," or "Tullu Nam-dur," and "Hora Finfinne" stand out as dominant spaces in Oromo place narratives (mythscapes), mainly for four reasons: First, it is a common knowledge in Oromo oral tradition that Walaabu is the mythical homeland of the Cushitic Oromo people; second, Walaabu serves as a reference point of alternative narrative counter to the phony outside-origin-theory made up by Abyssinian and Abyssinianist chroniclers for the Oromo; third, it can be used as a text analogous to the Christian myth of the Eden in Genesis. Fourth, Finfinne is a sacred site with a special meaning and significance to the Oromo who reclaim it today as a desecrated broken place.

For a similar argument about Oromo "origin theory" one may also consult Stephen Belcher's "The Oromo of Southern Ethiopia" in his African Myths of Origin (Belcher 2005). According to this Oromo origin myth, in the beginning, one male (waaqa, sky god) descended and found footprints that ultimately led him to one female (dachi, Mother Earth) and both produced children. The story represents metaphorically the continuing archetypal mythic union between the sky god (waaqa) and earth (dachii) in Oromo worldview to sustain life. Belcher's Oromo myth of human/social origin does not tell us where, though. The Oromo Earth Song, Dachi Nagaa Bultee (Good morning, Mother Earth), is another typical ecopoetic motif that resonates widely among the Oromo as part of a morning ritual, and this agricultural rite song embodies the close union between earth/environment and its inhabitants. Thus, what comes from culture comes from nature. In all accounts, these texts are more about the "beginning" than about "origin" because the "before-the-origin" texts are missing or nonexistent ${ }^{1}$. Hence, the question of the native through their folksongs and narratives is the same: "If this is your land, where are your stories?" (Chamberlin 2003; Steward 1955).

In this study, the ecopoetics of Oromo Orature has been considered a compelling case for the transformative cultural agency to explore the ethically challenged human-ecology relationships. Ecopoetics has been presented as an ecocultural creative process, as an act of aesthetic force of discourse that extends the human-ecology nexus beyond the mundane activities and use of nature to understanding the local perceptions/beliefs and their implications about the human close observation of, empathic interaction and ethical relationship to nature.

Ecopoetics takes as its focal point, I posit, the humankind responsible for the precarious state of the natural world as a result of the ongoing eco-colonialism and continuous urban expansion. To advance this cause and to decry the enduring environmental injustices intensified by insatiable material pursuit, this project made an attempt to reimagine folklore and ethnomusicology scholarship (academic or public) as a way of merging socioeconomic reality with environmentalism and as a platform for providing a face for the invisible but real presence of eco-colonialism both in industrialized and developing countries. The examples discussed in this study show that by singing their dislocated memories about the degradation and eviction from their home, the Oromo made a choice to keep their environmental history and to critique the social and environmental injustices through a folkloric representation of the dire human condition and the debilitating environment past and present.

\subsection{Ecological Archetypes}

An archetype is understood as the universal expression of particular patterns of behavior, feeling, thinking, and acting with a compelling influence on the human psyche beyond cultures. Folksongs can serve as a repertoire to identify ecological archetypes built around nature and Mother Earth (Dachi), analyze them from an ecopoetic perspective, and describe symbols, ideas, feelings, beliefs, and images representing the collective unconscious persistent across the culture.

1 (Cerulli 1922, p. 44) Citing Theophile Lefebure, Voyage in Abyssinia. Paris, 1845, Vol. 1, p. xv, for the mythic “Oromo Book of Knowledge" eaten by Ate-Loon, a Sacred Cow). 
Every culture has belief systems about human beings and the world in which they live. Aja among the Yoruba spirits is the Orisha (divine spirit), a forest spirit that protects animals and herbals, as Dryads and Oreads are Greek Nymphs or female spirits of trees and forests. Among the Oromo, Afiisolo, Caatto, and Shaye-Lagaa are spirits of the forest, while Ateete, Ogliya, Adbaarii, Qoollo, Geerii, and Daache relate to home, earth and land. Yet all are some of the Macca/Sibu Oromo guardian spirits that oversee man and the place of man in relation to nature.

When I interviewed the Oromo elders (Gurmu Badhaadha, Taddasa Galate, and Haile Tufo) in 2010 in Salale about the origin of Oromo folksongs, they said folksongs were composed in Oda Jila, Mogor valley, or in Haro Calanqo, in Jama gorges, or at Tullu Qaawa, near Ilu. According to my informant Taddasa Galate of Sole, Daalatti in Yaayya, this sound-world connectedness is real. He said that traditionally, songs are composed at Tulluu Qaawa where a spirit of an old lady is heard singing songs nonstop at night on the New Year. She is called Jaartii Qaawa or Jaartii Xoomi. Additionally, people offer sacrifices to learn new songs. Mabre Goofe and Gurmu share the view that Odaa Jilaa in Mogor and Holqa/Haroo Calanqoo in Jama are other sites for composing folksongs. At Holqa Calanqo, in Hidhabu Aboote, the deity called Abbaa Toochii is believed to guide the folksinger as a tutor and caretaker, and anyone who seeks the deity's refuge (my informants, Gameessa Gojee, age, 90; Gammada Tola, age, 92, in Hidhabuu Abootee 2010). According to Gurmu, for every new year and new harvest season, traditionally, the folksinger sojourns to Mogor River, climbs the Odaa Jila, sacred tree, carefully ties himself up with cord, in case he takes a nap, and meditates Ateete, the Oromo "Muse," covered up in the foliage for days and nights in confinement. After this ecopoetic process and creative "rites of passage," the folksinger comes home, a place of both sacred and secular significance, for a continuous group rehearsal. It needs further study to establish this native model of origin ... (my informant, Gurmuu Badhaadhaa, age 78, in Shararoo) ... By the same token, Vansina (1985) fieldwork experience about a Rwandese performer is a typical folkloric ecopoetic instance of composition of a folksong close to nature. In his own words, Vansina writes: "I have seen a poet on a hill in Rwanda mulling over his composition for hours, presumably day after day, until he felt it was perfect" (p. 12). Vansina's example of the Rwandese oral poet (folksinger) makes a case for a complete "deliberate composition" of a song rehearsed for performance until the performer felt it "perfect".

The Oromo esoteric knowledge of human-environment relations draws on ecological archetypes: motifs about spirits of the forest and Dachi/Mother Earth. Dachii is highly regarded as sacred in this Earth song next (informant, Gurmuu, 2010) because earth is believed to mediate and appease God (Waaqa) on behalf of humanity (nama), who lives to labor between the sky-god and earth, waaqaa-lafa [Text 4]:

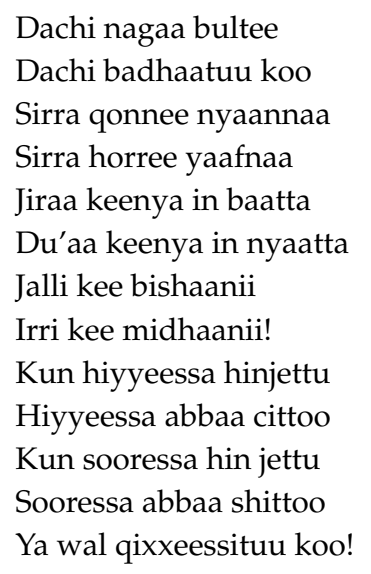

Good morning Mother Earth
Symbol of affluence and wealth
We live to plow and prosper on you
To bear and rear on you
You carry us alive on your back
And our dead back in your womb
Where water of life flows nonstop
And fertility, abundance, and crop!
You don't discriminate the poor
The poor with a skin rash
From the rich with sweet fragrance
All are equal kin and kith
Before your eyes, oh Mother Earth!

This common Earth Worship above is a motif that resonates widely among the Oromo as part of a morning ritual in farm fields. It embodies the close union between earth and humankind, unlike the Western humanism which emphasizes innate human capability and agency as well as rationalism. Hence, it is widely believed that human beings have a responsibility for the survival and sustainability 
of uumaa Waaqaa, God's creation, and creation, it is believed, does not belong to humans but to God and it takes place every new morning. This song in praise of Earth (Dachi) is a symbolic representation of a strong relationship (a song by Qeerroo 2015) the Oromo have with their land also evident in this song [Text 5]:

Yaa Oromoo, ya saba guddaa garaa qulqullu Qonnee nyaanna lafa hin gurgurru! oh, Oromo, the great nation on earth Say no to land grab and yes to till it!

The influence of the African traditional belief system is evident in the daily lives of the people including the agricultural rites of plowing, sowing, harvesting, funeral, birth, and wedding rituals, side by side with intense religious experience of Christianity and Islam. Morning is a sign of a good omen in the Oromo worldview about creation and fertility.

It is through their direct experiences that the local people gain insight into who they are in relation to the environment in which they live. The spirit communication through human and nonhuman beings, for example, through animal or rain symbolism that the people interpret as a good or bad omen, is followed by an incantation, a song or prayer, and a ritual performance to reverse what is believed to be bad luck (Paulitschke 1894 in Sigmund Freud 1950). The Oromo local knowledge tells us that when we go out to sow the farm, there is more to the deer that crosses our path, or to the woman/girl with an empty water jar that we meet on our way to set a marriage agreement. The people believe their instinct will always advise them to heed to the spirit communication to rethink and reverse the bad luck before making a decision to take or not to take some action.

There is lore of people's resentment to various controversial policies detrimental to the people's dependency on the environment. The creative and critical communication about harms made to the environment, and about the human-environment relationship, constitutes the ecopoetics of the everyday life of the people (Adugna 2014). To consider a broader conceptual schema of "critical folklore studies" about human-environment relations, it presupposes understanding local ecopoetics (poetics of ecology) as a creative and critical act, as an innate human capacity for critical thought about the environment in which they dwell (Gencarella, 2009). One can make a case for two environment-oriented Oromo proverbial metaphors next [Text 6]:

Illeettiin marga ofirratti hin dheeddu and

Risaan mannee ofiititti hin hagu
A rabbit does not eat and ruin the grass around its own den.

An eagle does not poop in its own nest.

In these two particular instances of social commentary, a few ecopoetic assumptions can be considered. First, by the established local social order, one should not ruin the "ecology," i.e., the "eco," oikos, from Greek, meaning "house" or "environment" as represented here by "den" and "nest". Second, the two texts can be understood as a disapproval of the eco-colonialism stance. It critiques the transnational corporations and economic powers of the Global North who reserve their own resources for future generations and turn to the Global South to seek cheap raw materials and cheap labor, for resource extraction and captive markets for their products, and to damp their toxic wastes. Third, put on an ideological scale, the texts are also critical of a broken place, i.e., a place devastated by the eco-colonial apathetic anthropogenic activities of the conservationist Western environmental attitude and power structures "proved to be incompatible with the indigenous concepts of conservation and human dignity" (WebCite).

\subsection{Love Songs, Ecological References}

It is a characteristic of modern Oromo lyrics to be rooted in the traditional, regional, and religious songs put in the wider context of the people's ecocultural, historical, and folkloric context. Some of the songs mention a place, a person, a mountain, a river or lake, a tree or animal, Waaqa (God), or earth. In another example, a folksinger laments the historical loss of land and natural resources, a revolutionary 
theme he introduced to the lyric titled "Amala Kee," ("Your Vibe") (Galaanaa Gaaromsaa, lyricist, WebCite, 2016) [Text 7]:

\author{
Salgan Haroo Abbaa Makoo \\ Iddoo gabaa hin qotani. \\ Dur manni keenya asoo \\ gamoo itti ijaarattanii.
}

\author{
The nine pools of Abba Makoo, \\ It is taboo to plow a marketplace. \\ Oh, our home used to be here \\ They evicted us to erect these buildings.
}

Nature and places represented in this song are ecological references to the ongoing land grab, eviction, rural-urban migration, urbanization and industrialization. Studies show that "Industrialization within the urban areas and conversion of different land use ... has caused the rapid depletion of existing tree cover during the past 100 years" (Shikur, WebCite). The current Oromo protest is more than opposition to the annexation of land and reclaiming Finfinne; rather it builds on the decades of protracted Oromo struggle for social and environmental justice. As part of the longstanding African tradition of folk culture, Oromo oral artistry wields a remarkable influence on the contemporary life of its society, it comments on the negative social transformation, such as eviction from ancestral land, which has affected the lives of millions of rural peasants and their families in their respective environment.

Most recently a lyric song titled "Maalin Jira!" meaning, "Distracted!" by the young Oromo artist, Hacaaluu Hundeessaa has gone viral on social media as it taps into the Oromo people's feelings of alienation, deprivation and resentment (Hacaalu Hundessaa, "Maalin Jira!"/“Distracted!" WebCite). This song expresses precisely the resentment of an individual who has been harassed and removed from his ancestral home, and in effect, confused and broken by strong feelings of homesickness, melancholy, and whose mind is troubled by nostalgia and a grief of historical loss and woeful love. When the conquest of the Oromoland was occurring in the 1880s, at the very same time the destruction of the original ecology was taking place. The lines below reiterate the deep-seated resentment about the loss of those places and ecology [Text 8]:

$\begin{array}{ll}\text { Gullalleen kan Tufaa } & \text { Gullalle of Tufaa } \\ \text { Gaara Abbichuu turii } & \text { Abbichu's mountainous land } \\ \text { Galaan Finfinnee dha..see } & \text { And Finfinne of Galan } \\ \text { Silaa akka jaalalaa } & \text { Love contains all } \\ \text { Walirraa hin fagaannuu } & \text { We never chose to grow apart, } \\ \text { Jara t' nu fageessee! } & \text { But they pushed us to fall! }\end{array}$

The ethnonyms Gullalle, Galan, and Gaara Abbichu are toponyms used to indicate the topographic features of the lands and to represent lineages of the same name of the Tulama branch. Major Harris of the British envoy wrote, thus, his eyewitness account of the first half of the 19th century (Harris 1844):

... rolling on like the mighty waves of the ocean, down poured the Amhara horse among the rich glades and rural hamlets, at the heels of the flying inhabitants-tramping underfoot the fields of the ripening corn, and sweeping before them the vast herds of cattle which grazed untended in every direction.

The conquest evicted the indigenous Oromo people in and around Finfinne and degraded the environment in which they lived by burning "village after village until the air was dark with their smoke mingled with the dust raised by the impetuous rush of man and horse," and reduced the citizens to serfs and slaves under subjugation (Harris 1844).

The bitterness was subdued by fear of repression and ostracism imposed by "Jara"/"They," the oppressors (line 6) throughout Oromo history until the nation/region-wide Oromo Protest broke out in 2014. Hence, the singer complains about the lack of unity and solidarity by alluding to his beloved whom he cannot see because of the mountain that divides them; the mountain being, metaphorically speaking, the oppressive system [Text 9]: 
Diiganii, gaara sana

Gaara diigamuu hin malle

$\mathrm{Nu}$ baasan adaan baane

$\mathrm{Nu}$ addaan bahuu hin malle
Level that mountain

Not easy to bulldoze

They rendered us asunder

Division we never chose

The feeling of love and desperation represented by a mountain is real and shared through the lyric which helps the ethnographer to chart the contours of rural consciousness to illuminate how place-based/ecological identities profoundly influence the people's understanding of politics from "below".

The Oromo historical and contemporary narratives show that the people participate in the spatial and environmental dynamics in traditional ways that predate industry, which requires the ethnoecologist folklorist to rely on the social-ecological memories of the communities evicted to live in a desolate place embracing both the environmental history and environmental folklore of the places. While their history is intertwined with the history of conquest and subjugation, a continued deprivation, marginalization, land grab, eviction, pollution, and resentment in the broader sweep of history, the Oromo people show a most enduring relationship with their places and resistance to forces who disrupt the relationship (The Human Rights Watch 2016).

In sum, the Oromo songs sung in farm fields, laments, love songs, hunting and historical songs, and performing ritual practices permeated the working lives of communities in the research area forming a distinctive ethnoecology that has been little examined. The songs offer valuable insights into understanding the 'ethnoecology' of the locale. Here, ethnoecology is understood as a "traditional set of environmental perceptions, that is, [a] cultural model of the environment and its relation to people and society" (Kottak 1999). For example, the Dachii/Mother Earth discourse approach can be well-suited to contribute to sustaining the well-being of planet earth and its habitats. The ecological archetype woven into personal memories is a rich source of ecopoetic data to synthesize the indigenous ecological knowledge system into a meaningful analytic whole.

\section{CODA: Return to Ecoculture}

This study concludes with some ecopoetic insights into the Oromo expressive culture (Orature) that the local Oromo ecological knowledge can be tapped into, to understand better the human-ecology relationships and to achieve justice in a social-ecological system at a disarray to date. The underlying aesthetic preoccupation of ecopoetics is predicated on the ideological and aesthetic (ideo-aesthetic) commitment to reveal the materialist underpinnings of eco-colonialism, i.e., environmentally motivated global capitalism. Once again, ecopoetics is a transdisciplinary theoretical stance that grows from within the humanities and social sciences to show solidarity with people's resistance from "below" against the predations of eco-colonialism by focusing on, among other preoccupations, exploring the dynamics of ecoculture, "tradition ecology", and "ecology of mind", that is, critiquing the commodification of environment; collecting and analyzing the ethnoecological data (folklore-oriented ecoculture) about the human-environment relationship, and human responsibilities and actions to save dachii, planet earth (Rappaport 1971). Given the urgency of environmental justice, historical and cultural contexts are imperative to help piece together the wider range of suffering that humanity have to live through, and the experience represented in personal narratives, folksongs, and performances stand as instances of a living witness. To do so, ecopoetics of folksongs and ecological archetypes creates a combination of transdisciplinary approaches to enrich the ecocultural texture and open up venues for an outreach in the wider research beyond humanities and social sciences.

Funding: The data used in this research came in part from my fieldwork in 2009 \& 2010 in Salale for my PhD project funded by Addis Ababa University, for which I remain very grateful.

Conflicts of Interest: The author declares no conflict of interest 


\section{References}

Adugna, Ashenafi Belay. 2014. Exploring Environmental Discourses in Oral Literature: Ecocritical Analysis of Oromo Proverbs. Journal of Languages and Culture 5: 24-35.

Arigo, Christopher. n.d. Notes Toward an Ecopoetics: Revising the Postmodern Sublime ... . Available online: https://www.asu.edu/pipercwcenter/how2journal/vol_3_no_2/ecopoetics/essays/pdfs/arigoessay.pdf (accessed on 5 May 2019).

Baisa, Lemmu. 1995. The Foundation and Development of Oromo Nationalism: Some Preliminary Observations. Oromo Commentary V: 15-16.

Basso, Keith. 1996. Wisdom Sits in Places. Albuquerque: University of New Mexico Press.

Bateson, Gregory. 1987. Steps to an Ecology of Mind. Northvale: Jason Aronson Inc.

Belcher, Stephen. 2005. African Myths of Origin. London: Penguin Books Ltd.

Central Statistical Agency. 2010. National-Statistics-Abstract-2010-Central Statistical Agency Section B Population-2010 Title. Available online: www.csa.gov.et (accessed on 15 August 2019).

Cerulli, Enrico. 1922. The Folk Literature of the [Oromo] of Southern Abyssinia. Harvard African Studies. Cambridge: Harvard University Press, Volume III.

Chamberlin, Edward. 2003. If This Is Your Land, Where Are Your Stories? Toronto: Alfred Knopf Canada.

Deme, Feyisa. 1998. The Origin of the Oromo: A Reconsideration of the Theory of the Cushitic Roots. Journal of Oromo Studies 5: 155-72.

Dibaba, Assefa Tefera. 2015. Ethnography of Resistance Poetics. Unpublished Ph.D. Dissertation, Department of Folklore \& Ethnomusicology, Indiana University, Bloomington, IN, USA.

Durning, A. T. 1992. Guardians of the Land: Indigenous Peoples and the Health of the Earth. Worldwatch Paper 112. Washington, DC: Worldwatch Institute.

Ehret, Christopher. 1976. Cushitic Prehistory. In East Lansing, Michigan. Edited by M Lionel Bender. East Lansing: African Studies Center, Michigan State U Press, pp. 85-96.

Estok, Simon C. 2009. Discourses of Nation, National Ecopoetics, and Ecocriticism in the face of the US: Canada and Korea as Case Studies. Comparative American Studies 7: 85-97.

Gifford, Terry. 2012. Towards a New Multi-Dimensional Ecopoetics of Place. A draft submitted for publication. Bath: Bath Spa University, September 14.

Harris, W.C. 1844. The Highlands of Ethiopia. 3 vols, London: Longman, Brown, Green, and Longman.

Hufford, Mary. 1999. Working in the Cracks: Public Space, Ecological Crisis, and the Folklorist. Journal of Folklore Research 36: 157-67.

Jalata, Asafa. 1996. The Struggle for Knowledge: The Case of Emergent Oromo Studies. African Studies Review 39: 95-123. [CrossRef]

Jalata, Asafa. 2012. Gadaa (Oromo Democracy): An Example of Classical African Civilization. Journal of Pan African Studies 5: 1.

Jeremias, M., A. Zenebe, M. Kenneth, L. Charles, T. Joseph, C. Delia, and J. Mowo. 2011. The Importance of Local Traditional Institutions in the Management of Natural Resources in the Highlands of Eastern Africa. Working Paper No. 134. Nairobi: World Agroforestry Centre.

Kamppinen, Matti. 2014. Religion from the Viewpoint of Tradition Ecology -Lauri Honko's (1932-2002) Contribution to Comparative Religion. Temenos 50: 13-37. [CrossRef]

Kamppinen, Matti, and Pekka Harkamies. 2012. The Theory of Culture of Folklorist Lauri Honko 1932-2002: The Ecology of Tradition. Lewiston: Mellen.

Kottak, Conrad P. 1999. The New Ecological Anthropology. American Anthropologist 10: 23-35. [CrossRef]

Labang, Oscar. 2015. “Toward A Postcolonial African Ecopoetics," Ecocultural Perspectives: Literature and Language. Edited by Oscar C. Labang. Raytown: Ken Scholars Publishing, pp. 13-32.

Latour, Bruno. 2011. Politics of nature: East and West Perspectives. Ethics \& Global Politics 4: 71-80.

Latour, Bruno, and S. C. Strum. 1986. "Human Social Origin" see "Story-telling and story tellers". Journal of Social Biological Structure 9: 169-87. [CrossRef]

Lodhi, Abdulaziz Y. 1993. The Language Situation in Africa Today. Nordic Journal of African Studies 2: 79-86.

Luling, Virginia. 1965. Government and Social Control among Some Peoples of the Horn of Africa. Master's thesis, University of London, London, UK. 
Mawere, Munyaradzi. 2013. Traditional Environment Conservation Strategies in Pre-Colonial Africa: Lessons from Zimbabwe to forget or to carry forward into the future. Afro Asian Journal of Social Sciences 4: 1-23.

Ministry of Environment, Forest and Climate Change, Ethiopia/Oromia. 2017. Oromia Forested Landscape Program Social Assessment. Addis Ababa. p. 23. Available online: https://reddplusethiopia.files.wordpress. com/2017/02/oflp-sesa-updated-8-feb-2017-clean-wb-rev.pdf (accessed on 17 November 2019).

Okpewho, Isidore. 1992. African Oral Literature: Background, Character, and Continuity. Bloomington \& Indianapolis: Indiana University Press.

Okpewho, Isidore. 2007. Introduction. Research in African Literatures 38: vii-xxi. [CrossRef]

Paulitschke, Philipp. 1894. Ethnography of Northeastern Africa. 2 vols, Berlin, (1893-96).

Rappaport, Roy A. 1971. Nature, Culture and Ecological Anthropology. In Man, Culture and Society. Edited by H. Shapiro. New York: Oxford University Press, pp. 237-68.

Saro-Wiwa, Ken. 1996. A message sent from prison, April 1995, upon winning the 1995 Goldman Environmental prize and quoted. National Geographic Magazine.

Shunkuri, Admasu. 1998. Irreecha Oromo Tradition in Thanksgiving: Its Assimilation in Ethiopia. Ethiopian Review 8: 42.

Slovic, Scott. 1999. Giving Expression to Nature: Voices of Environmental Literature. Environment 41: 6-32. [CrossRef]

Steward, Julian H. 1955. Theory of Culture Change: The Methodology of Multilinear Evolution. Urbana: The University of Illinois Press.

Thomasshow, Mitchell. 1996. Ecological Identity: Becoming a Reflective Environmentalist. Cambridge: MIT Press. Tibebu, Teshale. 1995. The Making of Modern Ethiopia: 1896-1974. Lawrenceville: The Red Sea Press. Vansina, Jan. 1985. Oral Tradition as History. Madison: The University of Wisconsin Press.

(C) 2020 by the author. Licensee MDPI, Basel, Switzerland. This article is an open access article distributed under the terms and conditions of the Creative Commons Attribution (CC BY) license (http://creativecommons.org/licenses/by/4.0/). 